\title{
Does The Financing Decision Help To Understand Market Reaction Around Mergers And Acquisitions?
}

Houssam Bouzgarrou, ISCAE-University of Manouba, Tunisia Waël Louhichi, ESSCA School of Management, France

\begin{abstract}
Few studies distinguish between the method of payment and the means of financing in mergers and acquisitions. This paper aims to test if the financing means has incremental information beyond that contained in the payment means. To answer this question, we consider a sample of 265 deals undertaken by French listed acquires between January 1997 and December 2008. We decompose our sample according to the method of payment (cash, stock or mixed payment). The difference of means test shows that the impact of the three methods of payment is not statistically significant. In order to take the analysis further, we then broke our sample down according to both the method of payment and the means of financing (debt, equity or internal funds). The difference of means test, the event study methodology and OLS regressions reveal that takeovers financed by debt outperform those financed by other means of financing. These findings confirm the monitoring role of debt and support the pecking order preferences. Finally, our OLS regressions highlight that market reaction depends also on legal environment (common law vs. non common law) on acquisition characteristics such as deal size and on acquirer specific factors such as size and growth opportunities.
\end{abstract}

Keywords: Mergers and Acquisitions; Abnormal Returns; Event Study; Means of Payment; Financing Decision

\section{INTRODUCTION}

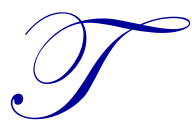

he choice of investment financing is a central issue in the field of corporate finance. Since the article of Modigliani and Miller (1958) abundant literature has focused on the impact of capital structure on firm value. Modigliani and Miller (1958) assume that in a perfect market with no-taxes, the financing decision is independent from the investment decision. Under this thesis, the choice of how investments are financed doesn't impact the stock market valuation. However, several studies show that Modigliani and Miller's (1958) proposition is irrelevant when we take into account taxes (Modigliani \& Miller, 1963), default costs (Myers, 1977) and agency costs (Jensen \& Meckling, 1976). Trade-off theory shows that optimal capital structure reflects both the tax advantages of debt less default costs, and agency costs resulting from asset substitution (Leland, 1998). An alternative thesis is supported by the market timing theory, which states that firms prefer external equity when the cost of equity is low, and prefer debt otherwise (DeAngelo et al., 2010; Huang \& Ritter, 2009; Baker \& Wurgler, 2002).

Mergers and acquisitions offer an appropriate framework to study the interaction between investment and financing decisions. Harris and Raviv (1988) and Stulz (1988) support the existence of financing preferences in mergers and acquisitions operations. According to these authors, the objective of owners-managers is to maintain control over the corporation and to avoid capital dilution. To solidify their control, managers prefer to finance mergers and acquisitions operations by debt or by internal resources rather than by issuing new equity. This intuition is in line with the pecking order theory initiated by Myers and Majluf (1984). The authors assume that firms prioritize their sources of financing, preferring internally generated funds. If internal resources are insufficient, firms prefer straight debt, then convertible debt, and finally external equity. Under this hypothesis, a stock financing of an 
acquisition could be interpreted by the market as a sign of overvaluation and hence would generate negative announcement abnormal returns. On the other hand, Cooney and Kalay (1993) develop a model in which an equity issue could signal a profitable investment opportunity and hence would generate potentially positive abnormal returns around the announcement date. This hypothesis is in line with Hansen's $(1984,1987)$ intuition, which argues that target shareholders prefer stock offers to cash offers when target equity is believed to be under evaluated.

In view of these contradictory results, the question of the impact of the means of financing investments on the market reaction around mergers and acquisitions remains pertinent. The goal of this paper is to test if there is a link between the means of financing investments and value creation around mergers and acquisitions operations. Few studies are interested in this issue as the literature has just focused on the examination of the means of payment of the operation. In these works, the differentiation was made between operations paid with stocks and those paid with cash (Travlos, 1987; Amihud et al., 1990; Faccio \& Masulis, 2005; Chemmanur et al., 2009; Harris et al., 2010, among others). However, in the latter case (cash payment), the takeover can be financed by debt, equity issuing or internal funds. In this paper we propose to fill this gap.

Our sample is composed of 265 mergers and acquisitions operations undertaken in French firms during the period between January 1997 and December 2008. Our results reveal a link between the choice of the means of financing and abnormal returns observed around the date of the operation. In fact, takeovers financed by debt outperform those financed by other means of financing.

The remainder of the paper is organised as follows. In Section 2, we present a brief literature review linked to our study. Afterwards, we detail our sample and our methodology. Section 4 summarises our main results. The last section concludes.

\section{LITERATURE REVIEW}

\subsection{The Impact of the Payment Method on Market Reaction around Mergers and Acquisitions}

Testing if mergers and acquisitions provide value creation or destruction for shareholders has interested the finance literature. Numerous works show that abnormal returns around mergers and acquisitions depend on different factors such as acquirer characteristics (Moeller et al., 2004), investor sentiment (Zhu, 2011) or the level of the targets' social and environmental practices (Aktas et al., 2011). Few studies have focused on the impact of the means of financing on bidder gains. Moreover, as documented by Schlingemann (2004), in many instances the form of payment has been used as a proxy or substitute for the source of financing. These studies distinguish between operations paid with stocks and takeovers paid by cash. There is consistent evidence that cash paid acquisitions are associated with better announcement performance. Travlos (1987) finds that acquirers that pay with stock realize $2.9 \%$ significant abnormal returns, and those that use cash payment realize $0.37 \%$ insignificant abnormal returns. Walker (2000) shows that there are no significant abnormal returns from stock offers but positive and significant abnormal returns (2.38\%) from cash offers. Moeller et al. (2004) take into account the size effect when comparing the announcement impact of cash and stock acquisitions. They find that large cash acquisitions gain $0.69 \%$ and that large stock acquisitions lose $-0.96 \%$. Moreover, the authors show that large acquirers of public targets lose $-2.45 \%$ if paying with stocks and lose only $-0.74 \%$ if paying with cash. Also, this study reveals that small bidders of public targets gain $2.84 \%$ if they pay with cash and lose $-0.41 \%$ if they pay with stocks. Dong et al. (2006) highlight a negative significant impact of payment with stocks on acquirer announcement returns, and a positive significant impact of payment with cash. The authors find that companies that pay for acquisitions with stocks exhibit a significant average value weighted book-to-market ratio of $-0.75 \%$ three days around the announcement. The main explanation of these results may be that acquirers will use stocks if they think that their shares are overvalued, and will pay with cash if they believe their shares undervalued or correctly valued (Shleifer \& Vishny, 2003; Chemmanur et al., 2009). An alternative explanation may be that acquirers decide on their payment method depending on whether they expect lower or higher performance in the forthcoming period. Myers and Majluf (1984) explain that using cash as a method of payment might serve as a signal to the market that the manager of the acquiring firm expects an increase in firm value over the post-acquisition period. The risk of dilution in share price and in ownership also represents an explanation of this result, as the number of shares increases, while the value of the firm remains the same until expected synergies take effect. 
Amihud et al. (1990) assume that corporate insiders who value control will prefer to finance investments by cash or debt rather than by issuing new stocks which dilute their holdings and increases the risk of losing control. The authors find that the likelihood of using cash financing is positively related to the managerial ownership fraction of the acquiring firm. They highlight that acquirers with low managerial ownership realize negative abnormal returns when they use stock financing method. Martin (1996) focuses on the impact of control threat on payment method. The author shows that acquirer managerial ownership is not related to the probability of stock payment over small and large ranges of ownership, but is negatively related over a middle range.

André and Ben-Amar (2010) examine the relation between family ownership and the method of payment. They confirm the presence of a control threat role. In fact, the authors find that the percentage of cash payment increases with the family's ultimate control stake. Harris et al. (2010) focus on the role of outside blockholders in determining the method of payment. The authors show that the likelihood of a cash offer increases when aggressive outside blockholding is in the intermediate ownership range, a range where their continued influence over managerial decision is threatened by a stock offer. Faccio and Masulis (2005) confirm the preference of acquisition cash payment when the voting control of the dominant shareholder is threatened. Moreover, the authors highlight the role of debt financing constraints in determining the payment choice.

\subsection{The Determinants of Mergers and Acquisitions Financing Choice}

Few studies distinguish between the method of payment and the method of financing in mergers and acquisitions. Schlingemann (2004) focuses on takeovers paid with cash. He examines the impact of different sources of this cash financing on acquirers abnormal returns. The author finds acquirer gains to be positively and significantly related to the amount of cash raised through equity issuance during the fiscal year preceding the acquisition announcement. Schlingemann (2004) explains this result by the decrease of uncertainty associated with the firm's decision to issue equity. Furthermore, this study reveals a negative and significant relation between internally generated free cash flows and acquirer abnormal returns, and an insignificant relation between the amount of cash raised from debt financing and abnormal returns.

Bharadwaj and Shivdasani (2003) suggest that bank debt performs an important certification and monitoring role for acquirers. They show that acquisitions whether entirely or partially financed by banks are associated with significantly positive announcement abnormal returns. This result is in line with the study of Billett et al. (1995), which highlights banks' certification and monitoring roles. Byers et al. (2008) show that bank monitoring may substitute for a firm's weak internal corporate governance structures. Indeed, banks are considered as specialized agents with the ability to produce information about the borrower more efficiently than securities markets. In the same vein, Leland and Pyle (1977) and Diamond (1984) consider banks respectively as producers of information and as delegated monitors. Since collecting information and monitoring are costly, the authors suggest delegating these tasks to banks in order to be more efficient.

Martynova and Renneboog (2009) measure acquirers' abnormal returns for different methods of payment and different sources of financing. They find, regardless of the source of payment, that cash paid and mixed paid acquisitions generate positive and significant abnormal returns. However, stock paid acquisitions generate negative insignificant abnormal returns. Focusing in financing decisions, the authors show that acquisitions financed by internal funds underperform those financed by debt. Moreover, takeovers that involve equity financing seem to generate a negative price reaction.

\section{METHODOLOGY AND DATA SELECTION}

\subsection{Methodology}

The aim of this paper is to examine the impact of the means of financing on bidder gains. We apply standard event study methodology to compute cumulative abnormal returns (CARs) around the announcement date. The standard returns are estimated using the market adjusted model, where the benchmark is the return of SBF 250 index. We use the market adjusted model to avoid potential contamination in estimation period due to multiple 
acquisitions. ${ }^{1}$ We consider different event windows: $(-2 ;+2),(0 ;+2)$ and $(0 ;+5)$. The Student test and the Wilcoxon test serve to determine whether abnormal returns are statistically different from zero.

Pooled regression models using the MacKinnon and White (1985)'s OLS heteroskedasticity-consistent standard errors and covariance procedure are employed over the 1997-2008 period. ${ }^{2}$ Our models aim to explain market reaction around mergers and acquisitions. We regress abnormal returns on the method of payment (cash, stock or mixed payment), on the financing means (debt, equity or internal funds) and on several control variables. Consequently, we run the following OLS models:

$$
\begin{aligned}
& C A R=\alpha_{0}+\alpha_{1} \text { Payment }+\alpha_{i} \text { Control }+\varepsilon \\
& C A R=\beta_{0}+\beta_{1} \text { Financing }+\beta_{i} \text { Control }+\mu
\end{aligned}
$$

Our control variables consider two categories of determinants: acquisition characteristics and acquirer characteristics.

Acquisition Characteristics: the acquisition characteristics that we control for are target country corporate governance regulation (common law vs. non common law), target status and relative deal size.

Corporate Governance Regulation: Cross-border mergers and acquisitions are considered as a mechanism to deviate from national corporate governance standards and to opt into another system. Goergen and Renneboog (2008) explain that firms may opt for less shareholder orientation or investor protection rather than for more stringent rules that require firms to focus on shareholder value. Martynova and Renneboog (2008) assume that acquirer's shareholder wealth increases when it acquires a target with lower corporate governance quality. We choose to control for common law corporate governance regulation of target country, rather than for cross-border acquisitions shortly, to capture the effect of investing in a stronger corporate governance regulation country. ${ }^{3}$ In our models, we introduce a dummy variable equal to one if the target country is regulation common law (La Porta et al., 1998), and zero otherwise. We expect a negative relation between target's governance regulation and abnormal returns.

Target Status: Fuller et al. (2002) and Faccio et al. (2006) show that acquirers of unlisted targets outperform acquirers of listed targets on announcement period using an American and a European sample, respectively. Officer (2007) explains this result by the fact that acquirers capture a liquidity discount when buying private or subsidiary targets. We introduce a dummy variable equal to one if the target is an unlisted firm. The relation between this variable and abnormal returns is expected to be positive.

Deal Size: Moeller et al. (2004) find that the relative deal size ratio is negatively related to acquirer abnormal returns. Bayazitova et al. (2010) show that mega-mergers, the top 1\% of mergers in absolute transaction value, on average, destroy value for the acquirer. We expect a negative relation between abnormal returns and the deal size measured by the deal value divided by acquirer's market value of assets.

Acquirer Characteristics: the acquirer traits that we control for are blockholder vote rights, firm size, growth opportunities, free cash flows, leverage and firm risk.

Blockholder Voting Rights: Shleifer and Vishny (1986) consider that a blockholder has substantial voting control to pressure management and pay for part of the gains that occur through acquisitions. The authors explain

\footnotetext{
${ }^{1}$ To check the robustness of our results we use market model to estimates expected returns with an estimation window of 251-day prior the announcement $(-261 ;-11)$. The results are qualitatively unchanged.

${ }^{2}$ MacKinnon and White's correction to cross-section standard errors has been employed to minimize potential autocorrelation problems and to allow for general contemporaneous correlations between the firm residuals in the OLS regression models. This correction is recommended for small size sample.

${ }^{3}$ La Porta et al. (1998) show that common law countries generally have the strongest, and French civil law countries the weakest, legal rules covering protection of corporate shareholders and creditors, with German and Scandinavian civil law countries located in the middle.
} 
that controlling outside shareholders, are viewed as agents of other outside owners, able to minimize poor managerial discretion if their control is sufficient to influence an ownership change. Empirical studies show that blockholders voting rights have an ambiguous effect on acquirer short term abnormal returns. While Ben-Amar and André (2006) show a positive impact of blockholders presence on performance, Masulis et al. (2007) find that institutional blockholders have an insignificant positive effect on acquirers' abnormal returns. Bauguess and Stegemoller (2008) distinguish between inside blockholders who are represented on the board of directors and outside blockholders who are not represented on the board. The authors find that the two types of blockholders have insignificant effects on acquisition performance. ${ }^{4}$

Firm Size: Several studies show that acquirer's size is negatively related to abnormal returns, that large acquirers, on average, pay higher premiums and make acquisitions that destroy firm value (Moeller et al., 2004). To test this hypothesis, we measure the firm size by the logarithm of total assets. The relation between acquirer's size and announcement abnormal returns is expected to be negative.

Growth Opportunities: Numerous works highlight that growth opportunities impact market reaction around Mergers and acquisitions. To control for this effect, we use Tobin's Q as a measure of growth opportunities. Taking into account the results of previous studies (Martynova \& Renneboog, 2009), we expect a negative relation between Tobin's $Q$ and abnormal returns.

Free Cash Flows: Jensen's (1986) hypothesis predicts a negative impact of current free cash flows on CAR, since managers of firms with a high level of free cash flows are more able to engage in empire building. However, higher free cash flows may indicate better recent firm performance, thus high quality of management. Empirically, Harford (1999) find that acquisitions by cash-rich firms are value decreasing and that this type of firm is more likely to make diversifying acquisitions and their targets are less likely to attract other acquirers. To test this hypothesis, the free cash flow is evaluated by the firm cash level divided book value of assets. The relation between free cash flow and abnormal return is expected to be negative.

Leverage: Stulz (1990) show that highly leveraged firms may suffer from an underinvestment problem because of a potential shareholders' wealth expropriation by creditors. Jensen (1986) and Stulz (1990) highlight the governance role of leverage since it discourages managers from empire building when free cash flows are high. In order to test these hypotheses, we measure leverage by dividing the acquirer long term debt by book value of assets.

Pre-Announcement Standard Deviation: Pre-announcement standard deviation should inform for firm risk and is expected to have a negative impact on acquirer abnormal returns.

\subsection{Sample Selection}

The sample of corporate acquisitions is drawn from completed deals undertaken by French listed acquirers between January 1997 and December 2008. Operations are identified from Thomson One Banker Merger and Acquisition Database. Acquisitions involving firms operating in highly regulated industries, such as financial and utility sectors, are excluded. Acquisitions are defined as occurring when the bidder controls less than $50 \%$ of the target's share before the announcement and more than $50 \%$ after the transaction. We limit our sample to acquisitions whose deal value is more than $€ 1$ million and which is at least $1 \%$ of the acquirer's market value of equity measured at the end of the fiscal year prior to the announcement date. Our initial sample includes with respect to these criteria 306 acquisitions.

To identify how acquirers finance their transactions, we have checked the news announcement from Factiva. Most news announcements do not disclose a very detailed description of the financing arrangement; the exact proportion of the sources is frequently not released when more than one financing source is used. Moreover, we can not distinguish whether equity financing occurs in the form of a public or private equity placement, or whether debt financing occurs by means of bank credit or a loan notes/bonds issue. Following Martynova and Renneboog (2009), we partition the financing sources into four categories: (i) internal funds only, (ii) debt issues, (iii) equity issues, and (iv) a combination of equity and debt issues. As internal funds financing is at least partially

\footnotetext{
${ }^{4}$ According to Faccio and Lang (2002), only $14 \%$ of French firms are widely held and $64.82 \%$ of firms are controlled by a single family. 
used in almost all acquisitions, we differentiate between transactions fully financed by internal funds and those that use internal funds with another financing source.

Acquirers' stock prices and accounting data are extracted from Datastream database. Ownership data is manually collected from Annual Report preceding and closest to the acquisition announcement. We use the same methodology as La Porta et al. (1999), Claessens et al. (2000) and Faccio and Lang (2002) to measure the ultimate cash flow and the voting held by the largest shareholders. Ownership and voting rights are measured as the weakest link in the control chain with respect to the presence of pyramids and double voting rule. After eliminating firms which announce more than one acquisition in the same day and acquirers which don't have available data, our final sample includes 265 acquisitions.

\subsection{Summary Statistics}

Table 1: Summary Statistics

\begin{tabular}{|l|c|c|c|c|c|c|c|c|c|c|}
\hline & \multicolumn{2}{c}{$\begin{array}{c}\text { All Sample } \\
(\mathbf{n = 2 6 5})\end{array}$} & \multicolumn{2}{c|}{$\begin{array}{c}\text { IF Financing } \\
(\mathbf{n = 3 9})\end{array}$} & \multicolumn{2}{c|}{$\begin{array}{c}\text { Debt Financing } \\
(\mathbf{n = 9 5})\end{array}$} & \multicolumn{2}{c|}{$\begin{array}{c}\text { Equity Financing } \\
(\mathbf{n}=\mathbf{8 4})\end{array}$} & $\begin{array}{c}\text { Debt \& Equity Fin. } \\
(\mathbf{n = 4 7})\end{array}$ \\
\hline
\end{tabular}

Notes: Ln Assets is the logarithm of book value of assets. Tobin's $Q$ is the sum of market value of assets and long term debt divided by the book value of assets. FCF is cash divided by book value of assets. Leverage is long term debt divided by book value of assets. Stand. Dev is the standard deviation of stock returns measured at the estimation period $(-261 ;-11)$. Block Own is cash flows rights of the ultimate shareholder. Block Vote is voting rights of the ultimate shareholder. RDS is the deal value divided by acquirer's market value of assets. Unlisted is equal to one if the target is unlisted firm, and zero otherwise. Com.Law is equal to one if target's country regulation is Common Law (La Porta et al., 1998), and zero otherwise. Cash Pay is equal to one if only cash is used for payment, and zero otherwise. Stock Pay is equal to one if only stocks are used for payment, and zero otherwise. Mixed Pay is equal to one if cash and stocks are used for payment, and zero otherwise.

Table 1 presents descriptive statistics of our sample by method of financing. Acquisitions financed by internal funds represent $14.7 \%$ (39 out of 265) of our sample; those financed by debt represent $35.8 \%$ (95 out of 265 ) and those by equity $31.7 \%$ (84 out of 265). Acquisitions financed by a combination of debt and equity represent $17.7 \%$ (47 out of 265). Panel A presents acquirer characteristics and shows that acquirers that use debt financing or a financing combination are bigger than those that use equity or internal funds. Statistics indicate that acquirers that use internal funds have a higher level of free cash flow (10\%) compared to other acquirers and also have a higher level of growth opportunities measured by Tobin's Q (2.06). These results show that free cash flows represent a good recent performance for these firms. Therefore, we expect positive abnormal returns for internal generally funds acquirers. Tobins' $\mathrm{Q}$ is also high and equal to 2.00 for equity financing acquirers compared to debt financing acquirers (1.23). Leverage is equal to $15 \%$ for debt financing acquirers, equal to $13 \%$ and to $12 \%$ for internal fund and equity financing acquirers, respectively. This result shows that firms that use debt as a means of financing, have higher leverage, and thus benefit already from banks' certification and monitoring roles. Ultimate shareholder ownership and voting rights are equal to $25 \%$ and $31 \%$, respectively, and are quite similar for all types of acquirers. This result is in line with the findings of La Porta et al. (1998) and Faccio and Lang (2002) concerning concentrated ownership in French market. According to La Porta et al. (1998), this result is due to the weakness of French corporate governance regulation. Panel B indicates that $34 \%$ of targets are from common law countries. Moreover, $44 \%$ of debt financed acquisitions and $26 \%$ of equity financed acquisitions are realized in these countries. 
Panel B also shows that the relative deal size of targets is equal to $37 \%$ if we consider the total sample. For internal funds financed acquisitions, this ratio is only equal to $4 \%$. We notice that $87 \%$ of these acquisitions targets are unlisted. The relative deal size is equal to $27 \%$ for debt financing acquisitions, equal to $52 \%$ for equity financed acquisitions and equal to $60 \%$ for acquisitions which require a combination of debt and equity. Finally, statistics indicate that internal funds and debt financed acquisitions are entirely cash paid. However, equity and combination financed acquisitions are paid with cash, with stock or with a mixed payment.

\section{RESULTS AND DISCUSSION}

In this section we present univariate analysis of acquirers' cumulative abnormal returns by payment method and by financing source. We also present results of OLS regressions using $[0 ;+2]$ event window. ${ }^{5}$

\subsection{Univariate Analysis}

Table 2 (Panel A) shows that French acquirers realize positive abnormal returns of 1.63\% five days around the announcement, significant at the level of $1 \%$. This result is robust to event window and is significantly equal to $1.60 \%$ and $1.35 \%$ respectively two and five days following the announcement. Panel A shows that acquirers that pay with cash, realize significant abnormal returns of $2.04 \%$ two days following the announcement. However, acquirers that use stocks or a mixture of cash and stocks realize positive insignificant mean abnormal returns using different event windows. Five days following the announcement, we find that these acquirers realize negative insignificant median abnormal returns. The difference of means test reported in Panel A shows that the impact of the three methods of payment is not statistically significant. Also, the difference of means between cash paid acquisitions and non cash paid acquisitions is insignificant.

Table 2: Acquirers' Cumulative Abnormal Returns

\begin{tabular}{|c|c|c|c|c|c|c|}
\hline & \multicolumn{2}{|c|}{ CAR $[-2 ;+2]$} & \multicolumn{2}{|c|}{ CAR $[0 ;+2]$} & \multicolumn{2}{|c|}{ CAR $[0 ;+5]$} \\
\hline & Mean & Median & Mean & Median & Mean & Median \\
\hline \multicolumn{7}{|l|}{ Panel A: By Method of Payment } \\
\hline All Sample (265): & $1.63 * * *$ & $0.86^{* * *}$ & $1.60 * * *$ & $0.72 * * *$ & $1.35 * *$ & $0.72 * *$ \\
\hline Cash payment (182) & $1.70 * * *$ & $0.89 * * *$ & $2.04 * * *$ & $0.76^{* * *}$ & $1.73 * * *$ & $1.08 * * *$ \\
\hline Stock payment (50) & 1.76 & 0.66 & 0.30 & -0.12 & 0.42 & -1.17 \\
\hline Mixed payment (33) & 1.03 & 0.45 & 1.16 & 1.41 & 0.69 & -1.25 \\
\hline Kurskal-Wallis Test & & 0.35 & & 2.83 & & 1.99 \\
\hline Diff. Cash Pay - NonCash Pay & -0.22 & -0.48 & -1.45 & -1.53 & -1.01 & -1.36 \\
\hline \multicolumn{7}{|l|}{ Panel B: By Method of Financing } \\
\hline Internal Funds (39): & 1.63 & $1.18 *$ & $1.80 * *$ & $1.32 * *$ & 2.16 & $1.70 * *$ \\
\hline Cash payment & 1.63 & $1.18^{*}$ & $1.80 * *$ & $1.32 * *$ & 2.16 & $1.70 * *$ \\
\hline Debt Financing (95): & $2.39 * * *$ & $1.71 * * *$ & $2.91 * * *$ & $1.91 * * *$ & $2.44 * * *$ & $1.52 * * *$ \\
\hline Cash payment & $2.39 * * *$ & $1.71 * * *$ & $2.91 * * *$ & $1.91 * * *$ & $2.44 * * *$ & $1.52 * * *$ \\
\hline Equity Financing (84): & 1.55 & 0.69 & 0.74 & 0.24 & 0.62 & 0.18 \\
\hline Cash payment (20) & 0.02 & 0.12 & 0.07 & 0.03 & -1.30 & 0.16 \\
\hline Sock payment (39) & 2.21 & 2.72 & 0.58 & 0.12 & 0.97 & 0.15 \\
\hline Mixed payment (25) & 1.73 & 1.38 & 1.53 & 2.44 & 1.62 & 2.53 \\
\hline Debt and equity (47): & 0.23 & -1.87 & 0.32 & -1.26 & -0.17 & -1.31 \\
\hline Cash payment (28) & 0.67 & 0.13 & 0.80 & -0.48 & 0.91 & -0.17 \\
\hline Stock payment (11) & 0.14 & -1.87 & -0.67 & -2.14 & -1.49 & -1.31 \\
\hline Mixed payment (8) & -1.14 & -3.30 & 0.00 & -1.01 & -2.19 & -2.90 \\
\hline Kurskal-Wallis Test & & $7.06 *$ & & $10.66 * *$ & & $8.38 * *$ \\
\hline Diff. Debt Fin - NonDebt Fin & -1.17 & $-1.90 *$ & $-2.22 * *$ & $-2.72 * * *$ & -1.48 & $-2.20 * *$ \\
\hline Diff. Equ Fin - NonEqu Fin & 0.11 & 0.13 & 1.32 & 1.28 & 0.91 & 1.15 \\
\hline
\end{tabular}

Cumulative abnormal returns are calculated using market adjusted model. Numbers in parenthesis are acquisitions' numbers. Student and Wilcoxon tests are used for mean and median, respectively. Tests of the difference in abnormal return are based on Student and Mann-Whitney, for mean and median respectively. Test of difference in abnormal returns between different payment (financing) methods are based on KurskalWallis test. $* * *, * *$ and $*$ denote significance at the $1 \%, 5 \%$ and $10 \%$ levels, respectively.

\footnotetext{
${ }^{5}$ To check robustness of our results we use $(-2 ;+2)$ and $(0 ;+5)$ windows. Results are qualitatively unchanged.
} 
In order to take the analysis further, we then broke our sample down according to both the method of payment and the means of financing. Panel B reports cumulative abnormal returns by method of financing. We find that internal funds acquirers realize positive abnormal returns of $1.80 \%$ significant at the level of $5 \%$. This result indicates that the high level of free cash flows, found in descriptive statistics, represents recent performance of these firms. Panel B also shows that prices increase significantly by $2.91 \%$ when debt is used to finance the acquisition. However, we find insignificant abnormal returns of $0.74 \%$ and $0.32 \%$ respectively when equity financing and combination financing are used. The Kurskal Wallis test shows a significant difference between the four methods of financing. The difference of means between debt and non debt financing is significant which indicates that takeovers financed by debt outperform those financed by other sources. Furthermore, results reported by Panel B show that the significant abnormal returns in cash paid acquisitions, detected in Panel A, depend on the source of financing. Takeovers paid by cash significantly create value only when the source of financing is debt or internal funds. These findings support the existence of financing preferences in mergers and acquisitions operations.

\subsection{Multivariate Analysis}

Table 3: Payment Method Impact on Acquirer Announcement Cars

\begin{tabular}{|c|c|c|c|c|}
\hline Independent Variable & Expected Sign & (1) & (2) & (3) \\
\hline Cash Payment & + & $\begin{array}{c}0.016 \\
(0.155)\end{array}$ & & \\
\hline Stock Payment & - & & $\begin{array}{l}-0.015 \\
(0.328)\end{array}$ & \\
\hline Mixed Payment & $+/-$ & & & $\begin{array}{l}-0.006 \\
(0.671)\end{array}$ \\
\hline Common Law & - & $\begin{array}{c}-0.020 * * \\
(0.039)\end{array}$ & $\begin{array}{c}-0.019 * * \\
(0.050)\end{array}$ & $\begin{array}{l}-0.017 * \\
(0.064)\end{array}$ \\
\hline Unlisted Target & + & $\begin{array}{c}0.003 \\
(0.741)\end{array}$ & $\begin{array}{c}0.004 \\
(0.677)\end{array}$ & $\begin{array}{c}0.006 \\
(0.479)\end{array}$ \\
\hline Relative Deal Size & - & $\begin{array}{l}-0.012 \\
(0.138)\end{array}$ & $\begin{array}{l}-0.012 \\
(0.105)\end{array}$ & $\begin{array}{l}-0.013 * \\
(0.092)\end{array}$ \\
\hline Blockholder Votes & $+/-$ & $\begin{array}{c}0.023 \\
(0.191)\end{array}$ & $\begin{array}{c}0.253 \\
(0.171)\end{array}$ & $\begin{array}{c}0.025 \\
(0.167)\end{array}$ \\
\hline Ln Total Assets & - & $\begin{array}{c}-0.004 * * \\
(0.047)\end{array}$ & $\begin{array}{c}-0.004 * \\
(0.051)\end{array}$ & $\begin{array}{l}-0.004 * \\
(0.052)\end{array}$ \\
\hline Tobin's Q & - & $\begin{array}{c}-0.006^{*} \\
(0.090)\end{array}$ & $\begin{array}{l}-0.006 \\
(0.108)\end{array}$ & $\begin{array}{l}-0.006^{*} \\
(0.082)\end{array}$ \\
\hline Free Cash Flow & - & $\begin{array}{c}0.180 \\
(0.125)\end{array}$ & $\begin{array}{c}0.177 \\
(0.141)\end{array}$ & $\begin{array}{c}0.182 \\
(0.106)\end{array}$ \\
\hline Leverage & $+/-$ & $\begin{array}{l}-0.031 \\
(0.397)\end{array}$ & $\begin{array}{l}-0.257 \\
(0.498)\end{array}$ & $\begin{array}{l}-0.023 \\
(0.527)\end{array}$ \\
\hline Standard Dev & - & $\begin{array}{l}0.935^{*} \\
(0.092)\end{array}$ & $\begin{array}{c}0.852 \\
(0.117)\end{array}$ & $\begin{array}{c}0.771 \\
(0.166)\end{array}$ \\
\hline Constant & & $\begin{array}{c}0.051 \\
(0.219)\end{array}$ & $\begin{array}{c}0.065 \\
(0.114)\end{array}$ & $\begin{array}{c}0.064 \\
(0.122)\end{array}$ \\
\hline $\mathrm{N}$ obs & & 265 & 265 & 265 \\
\hline F-Stat & & $2.32 * *$ & $2.41 * * *$ & $2.11 * *$ \\
\hline Adjusted $\mathrm{R}^{2}$ & & 0.086 & 0.084 & 0.079 \\
\hline
\end{tabular}

Dependent variable is CAR $[0 ;+2]$. Cash Payment is equal to one if only cash is used for payment, and zero otherwise. Stock Payment is equal to one if only stocks are used for payment, and zero otherwise. Mixed Payment is equal to one if both cash and stocks are used for payment, and zero otherwise. Common Law is equal to one if target's country regulation is Common Law (La Porta et al., 1998), and zero otherwise. Unlisted Target is equal to one if the target is unlisted firm, and zero otherwise. Relative Deal Size is the deal value divided by acquirer's market value of assets. Blockholder Votes is voting rights of the ultimate shareholder. Ln Total Assets is the logarithm of book value of assets. Tobin's $Q$ is the sum of market value of assets and long term debt divided by the book value of assets. Free Cash Flow is cash divided by book value of assets. Leverage is long term debt divided by book value of assets. Standard Dev is the standard deviation of stock returns measured at the estimation period $(-261 ;-11)$. Statistical significance is corrected for heterocedasticity using MacKinnon and White (1985) adjustment. ***, ** and * denote significance at the $1 \%, 5 \%$ and $10 \%$ levels, respectively.

Table 3 presents regression results of the impact of cash and stock payments on acquirer's abnormal returns computed through the event window $[0 ;+2]$. Model (1) shows a positive insignificant impact of cash payment on abnormal returns. However, Model (2) reveals a negative insignificant impact of stock payment on abnormal returns. These results confirm our univariate findings for stock paid acquisitions and for the test of difference 
between cash and non cash payment. We find, in the two models, a negative insignificant relationship between abnormal returns and ultimate shareholder with moderate voting rights level. All models show that the acquisition of targets from common law countries has negative significant impact on short term performance. This result indicates that a French acquirer's shareholder wealth decreases when it acquires a target with higher corporate governance quality. We also find, similarly to Moeller et al. (2004) and Martynova and Renneboog (2009), a negative significant impact of firm size and growth opportunities on abnormal returns. Contrary to Harford (1999) and Moeller et al. (2004), we didn't find a significant impact of free cash flows on abnormal returns. The other control variables (leverage, risk level, relative deal size and listing of the target firm) are also insignificant.

Table 4 summarizes the results of regressions testing the impact of internal funds, debt and equity financing on acquirer's abnormal returns. According to our first model, internal funds financing has a positive insignificant relationship with abnormal returns. Model (2) shows that debt financing is positively and significantly related to announcement performance. Model (3) highlights the negative impact of equity financing on abnormal returns. The last model indicates that a combination of financing means doesn't impact market reaction. Together, these findings show that takeovers financed by debt outperform those financed by other means, which support the monitoring role of debt and confirm the pecking order preferences. Also, it seems that stock financing is interpreted by investors as a signal of overvaluation and leads to a negative market reaction (Myers \& Majluf, 1984).

Table 4: Financing Method Impact on Acquirer Announcement Cars

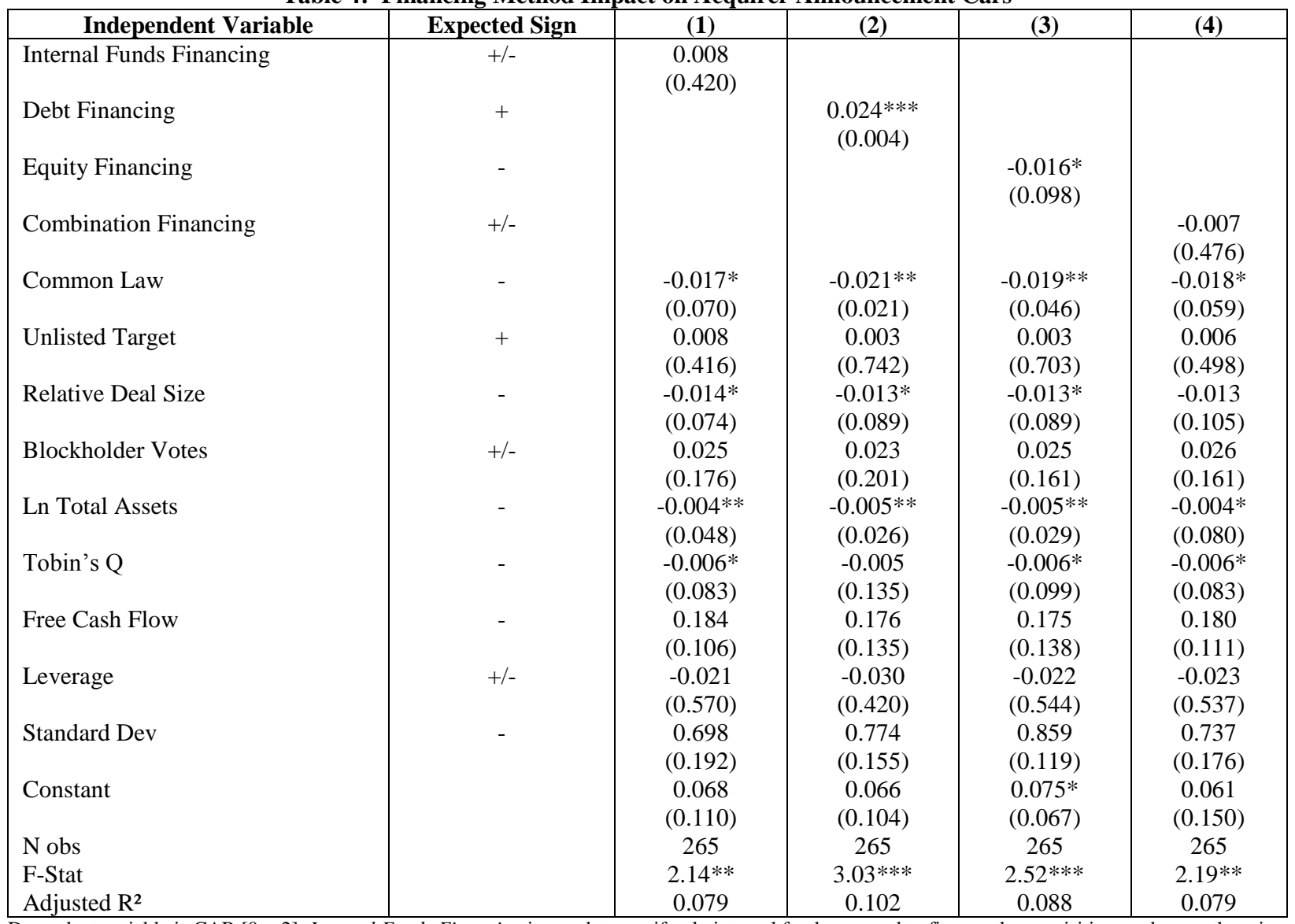

Dependent variable is CAR [0; +2]. Internal Funds Financing is equal to one if only internal funds are used to finance the acquisition, and zero otherwise. Debt Financing is equal to one if debt is used to finance the acquisition, and zero otherwise. Equity Financing is equal one if equity is used to finance the acquisition, and zero otherwise. Combination Financing is equal one if both debt and equity are used to finance the acquisition, and zero otherwise. Common Law is equal to one if target's country regulation is Common Law (La Porta et al., 1998), and zero otherwise. Unlisted Target is equal to one if the target is unlisted firm, and zero otherwise. Relative Deal Size is the deal value divided by acquirer's market value of assets. Blockholder Votes is voting rights of the ultimate shareholder. Ln Total Assets is the logarithm of book value of assets. Tobin's $Q$ is the sum of market value of assets and long term debt divided by the book value of assets. Free Cash Flow is cash divided by book value of assets. Leverage is long term debt divided by book value of assets. Standard Dev is the standard deviation of stock returns measured at the estimation period $(-261 ;-11)$. Statistical significance is corrected for heterocedasticity using MacKinnon and White (1985) adjustment. $* * *, * *$ and $*$ denote significance at the $1 \%, 5 \%$ and $10 \%$ levels, respectively. 
In all our models, we find that a moderate level of voting rights has a negative insignificant impact on returns. Also, the coefficients of the variables common law, firm size and growth opportunities are negative and significant which confirm the results found above in Table 3. Furthermore, the relative deal size of target has a moderate (significant at $10 \%$ level) negative impact on abnormal returns which indicates that the higher the target size relative to the acquisition, the lower the value creation. Finally, the variables leverage, risk and listing of the target firm remain insignificant.

\section{CONCLUSION}

This paper aims to study the impact of means of financing on market reaction around mergers and acquisitions. Few works are interested in this issue as the literature has just focused on the role of the payment method. Previous studies distinguish between takeovers paid with stocks and those paid with cash. However, in the latter case (cash payment), operations can be financed by debt, equity issuing or internal funds. In this study, we propose to break down our sample according to both the method of payment and the means of financing (debt, equity or internal funds). Our results show that the financing means has incremental information beyond that contained in the payment method. We highlight a strong link between the choice of the means of financing and abnormal returns observed around the date of the event. Indeed, the difference of means test, the event study methodology and OLS regressions show that takeovers financed by debt outperform those financed by other means of financing. Moreover, it seems that the market reaction also depends on the legal environment, on acquirer specific factors and on acquisition characteristics. Abnormal returns fall for risky, high-growth bidders, and when acquiring target from common law countries.

\section{AUTHOR INFORMATION}

Dr. Houssam Bouzgarrou is currently an Associate Professor of Finance at ISCAE - University of Manouba. He was previously an Assistant Professor at Rennes 1 University (France). He is a researcher at CREM Rennes (UMR 6211 CNRS). His research interests are M\&A, corporate governance and banking. He obtained a Ph.D from Rennes 1 University. He has published several articles in international journals (International Review of Financial Analysis, International Journal of Business and Finance Research, Bankers, Markets and Investors, etc.).

Dr. Waël Louhichi is currently a Professor of Finance at ESSCA School of Management. He was previously a Associate Professor of Finance at Rennes 1 University and Assistant Professor at Amiens School of Management. He obtained a Ph.D from both Perpignan University (France) and Louvain School of Management (Belgium). He has published several articles in international journals (International Review of Financial Analysis, Review of Accounting and Finance, Applied Financial Economics, Journal of Asset Management, Journal of Applied Business Research, Management Decision, Applied Economics Letters, Applied Economics, etc.). E-mail: louhichiwael@yahoo.fr (Corresponding author)

\section{REFERENCES}

1. Aktas, N., De Bodt, E., \& Cousin, J. G. (2011). Do financial markets care about SRI? Evidence from mergers and acquisitions. Journal of Banking \& Finance, 35, 1753-1761.

2. Amihud, Y., Lev, B., \& Travlos, N. (1990). Corporate control and the choice of investment financing: The case of corporate acquisitions. Journal of Finance, 45, 603-616.

3. André, P., \& Ben-Amar, W. (2010). Family control and financing decisions in mergers and acquisitions. (Working Paper). IFSAM.

4. Baker, M., \& Wugler, J. (2002). Market timing and capital structure. Journal of Finance, 57, 1-32.

5. Bauguess, S., \& Stegemoller, M. (2008). Protective governance choices and the value of acquisition activity. Journal of Corporate Finance, 14, 550-566.

6. Bayazitova, D., Kahl, M., \& Valkanov, R. (2010). Which mergers destroy value? Only mega mergers. (Working Paper).

7. Ben-Amar, W., \& André, P. (2006). Separation of ownership from control and acquiring firm performance: The case of family ownership in Canada. Journal of Business Finance and Accounting, 33, 517-543. 
8. Bharadwaj, A., \& Shivadasani, A. (2003). Valuation effects of bank financing in acquisitions. Journal of Financial Economics, 67, 113-148.

9. Billett, M., Flannery, M., \& Garfinkel, J. (1995). The effect of lender identity on a borrowing firm's equity return. Journal of Finance, 50, 699-718.

10. Byers, S. S., Fields, L. P., \& Fraser, D. R. (2008). Are corporate governance and bank monitoring substitutes: Evidence from the perceived value of bank loans. Journal of Corporate Finance, 14, 475-483.

11. Chemmanur, T, J., Paeglis, I., \& Simonyan, K. (2009). The medium of exchange in acquisitions: Does the private information of both acquirer and target matter? Journal of Corporate Finance, 15, 523-542.

12. Claessens, S., Djankov, S., \& Lang, L. H. P. (2000). The separation of ownership and control in East Asian corporations. Journal of Financial Economics, 58, 81-112.

13. Cooney Jr., J. W., \& Kalay, A. (1993). Positive information from equity issue announcements. Journal of Financial Economics, 33, 149-172.

14. DeAngelo, H., DeAngelo, L., \& Stulz, R. M. (2010). Seasoned equity offerings, market timing, and the corporate lifecycle. Journal of Financial Economics, 95, 275-295.

15. Diamond, D. (1984). Financial intermediation and delegated monitoring. Review of Economic Studies, 51, 393-414.

16. Dong, M., Hirshleifer, D., Richardson, S., \& Teoh, S. H. (2006). Does investor misevaluation drive the takeover markets? Journal Finance, 61, 725-762.

17. Faccio, M., \& Lang, L. H. P. (2002). The ultimate ownership of Western European corporations. Journal of Financial Economics, 65, 365-395.

18. Faccio, M., \& Masulis, R. W. (2005). The choice of payment method in European mergers and Acquisitions. Journal of Finance, 60, 1345-1388.

19. Faccio, M., McConnell, J., \& Stolin, D. (2006). Returns to acquirers of listed and unlisted Targets. Journal of Financial and Quantitative Analysis, 41, 197-220.

20. Fuller, K., Netter, J., \& Stegemoller, M. (2002). What do returns to bidding firms tell us? Evidence from firms that make many acquisitions. Journal of Finance, 57, 1763-1793.

21. Goergen, M., \& Renneboog, L. (2008). Contractual corporate governance. Journal of Corporate Finance, 14, 166-182.

22. Hansen, R. G. (1984). Information asymmetry and the means of payment in auction. Working Paper, Amos Tuck School of Business, Dartmouth College.

23. Hansen, R. G. (1987). A theory for the choice of exchange medium in mergers and acquisitions. Journal of Business, 60, 75-95.

24. Harford, J. (1999). Corporate cash reserves and acquisitions. Journal Finance, 54, 1969-1997.

25. Harris, O., Madura, J., \& Glegg, C. (2010). Do managers make takeover financing decisions that circumvent more effective outside blockholders? The Quarterly Review of Economics and Finance, 50, 180-190.

26. Harris, M., \& Raviv, A. (1988). Corporate control contests and capital structure. Journal of Financial Economics, 20, 55-86.

27. Huang, R., \& Ritter, J. (2009). Testing theories of capital structure and estimating the speed of adjustment. Journal of Financial and Quantitative Analysis, 44, 237-271.

28. Jensen, M. C. (1986). Agency cost of free cash flows, corporate finance and takeover. American Economic Review, 76, 323-329.

29. Jensen, M., \& Meckling, W. (1976). Theory of the firm: Managerial behaviour, agency costs and ownership structure. Journal of Financial Economics, 3, 305-360.

30. La Porta, R., Lopez-de-Silanes, F., Shleifer, A., \& Vishny, R. (1998). Law and finance. Journal of Political Economy, 106, 1113-1155.

31. La Porta, R., Lopez-de-Silanes, F., \& Shleifer, A. (1999). Corporate ownership around the World. Journal of Finance, 54, 471-517.

32. Leland, H. E. (1998). Agency costs, risk management anti capital structure. Journal of Finance, 53, $1213-$ 1243.

33. Leland, H. E., \& Pyle, D. (1977). Information asymmetries, financial structure and financial intermediaries. Journal of Finance, 32, 371-387.

34. MacKinnon, J. G, \& White, H. (1985). Some heteroskedasticity consistent covariance matrix estimators with improved finite sample properties. Journal of Econometrics, 29, 53-57. 
35. Martin, K. J. (1996). The method of payment in corporate acquisitions, investment opportunities, and management ownership. The Journal of Finance, 51, 1227-1246.

36. Martynova, M., \& Renneboog, L. (2008). Spillover of corporate governance standards in cross-border mergers and acquisition. Journal of Corporate Finance, 14, 200-223.

37. Martynova, M., \& Renneboog, L. (2009). What determines the financing decision in corporate takeovers: Cost of capital, agency problems, or the means of payment? Journal of Corporate Finance, 15, 290-315.

38. Masulis, R. W., Wang, C., \& Xie, F. (2007). Corporate governance and acquirer returns. The Journal of Finance, 62, 1851-1889.

39. Moeller, S. B., Schlingemann, F. P., Stulz, R. M. (2004). Firm size and the gains from acquisitions. Journal of Financial Economics, 73, 201-228.

40. Modigliani, F., \& Miller, M. (1958). The cost of capital, corporation finance, and the theory of investment. American Economic Review, 48, 261-275.

41. Modigliani, F., \& Miller, M. (1963). Corporate income taxes and the cost of capital: A correction. American Economic Review, 53, 433-443.

42. Myers, S. C. (1977). Determinants of corporate borrowing. Journal of Financial Economics, 5, $147-175$.

43. Myers, S. C, \& Majluf, N. S. (1984). Corporate financing and investment decisions when firms have information that investors do not have. Journal of Financial Economics, 13, 187-221.

44. Officer, M. S. (2007). The price of corporate liquidity: Acquisition discounts for unlisted targets. Journal of Financial Economics, 83, 571-598.

45. Schlingemann, F. (2004). Financing decisions and bidder gains. Journal of Corporate Finance, 10, $683-$ 701.

46. Shleifer, A., \& Vishny, R. (1986). Large shareholders and corporate control. Journal of Political Economy, 94, 461-488.

47. Shleifer, A., \& Vishny, R. (2003). Stock market driven acquisitions. Journal of Financial Economics, 70 , 295-311.

48. Stulz, R. (1988). Managerial control of voting rights: Financing policies and the market for corporate control. Journal of Financial Economics, 20, 25-54.

49. Stulz, R. M. (1990). Managerial discretion and optimal financing policies. Journal of Financial Economics, 26, 3-27.

50. Travlos, N. G. (1987). Corporate takeover bids, methods of payment, and bidding'stock returns. Journal of Finance, 42, 943-963.

51. Walker, M. (2000). Corporate takeovers, strategic objectives, and acquiring firm shareholder wealth. Financial Management, 29, 53-66.

52. Zhu, P. C. (2011). Persistent performance and interaction effects in sequential cross-border mergers and acquisitions. Journal of Multinational Financial Management, 21, 18-39. 


\section{Appendix 1: Definition of Variables}

\begin{tabular}{|c|c|}
\hline Variable & Definition \\
\hline CAR & $\begin{array}{l}\text { Cumulative abnormal return two days following the announcement }[0 ;+2] \text {, } \\
\text { measured using market model. }\end{array}$ \\
\hline Cash Payment & A dummy variable equal to one if only cash is used for payment, and zero otherwise. \\
\hline Stock Payment & $\begin{array}{l}\text { A dummy variable equal to one if only stocks are used for payment, and zero } \\
\text { otherwise. }\end{array}$ \\
\hline Mixed Payment & $\begin{array}{l}\text { A dummy variable equal to one if both cash and stocks are used for payment, and } \\
\text { zero otherwise. }\end{array}$ \\
\hline Internal Funds Financing & $\begin{array}{l}\text { A dummy variable equal to one if only internal funds are used to finance the } \\
\text { acquisition, and zero otherwise. }\end{array}$ \\
\hline Debt Financing & $\begin{array}{l}\text { A dummy variable equal to one if debt is used to finance the acquisition, and zero } \\
\text { otherwise. }\end{array}$ \\
\hline Equity Financing & $\begin{array}{l}\text { A dummy variable equal one if equity is used to finance the acquisition, and zero } \\
\text { otherwise. }\end{array}$ \\
\hline Combination Financing & $\begin{array}{l}\text { A dummy variable equal one if both debt and equity are used to finance the } \\
\text { acquisition, and zero otherwise. }\end{array}$ \\
\hline Common Law & $\begin{array}{l}\text { A dummy variable equal to one if target's country regulation is Common Law (La } \\
\text { Porta et al., 1998), and zero otherwise. }\end{array}$ \\
\hline Unlisted Target & A dummy variable equal to one if the target is unlisted firm, and zero otherwise. \\
\hline Deal Size & $\begin{array}{l}\text { Measured by the relative deal size ratio by dividing the deal value by acquirer's } \\
\text { market value of assets. }\end{array}$ \\
\hline Blockholder Votes & $\begin{array}{l}\text { The voting rights of the ultimate shareholder measured as the weakest link in the } \\
\text { control chain with respect to the presence of pyramids and double voting rule, } \\
\text { following La Porta et al. (1999), Claessens et al. (2000) and Faccio and Lang (2002). }\end{array}$ \\
\hline Firm Size & Measured by the logarithm of book value of assets. \\
\hline Growth Opportunities & $\begin{array}{l}\text { Measured by the Tobin's Q by dividing the sum of market value of assets and long } \\
\text { term debt by the book value of assets. }\end{array}$ \\
\hline Free Cash Flow & Cash divided by book value of assets. \\
\hline Leverage & Measured by the dividing the long term debt by the book value of assets. \\
\hline Firm Risk & $\begin{array}{l}\text { Measured by the standard deviation of stock returns at the estimation period (-261; } \\
11) \text {. }\end{array}$ \\
\hline
\end{tabular}


Appendix 2: Pairwise Correlation Matrix

\begin{tabular}{|c|c|c|c|c|c|c|c|c|c|}
\hline & $\begin{array}{c}\text { Common } \\
\text { Law }\end{array}$ & $\begin{array}{c}\text { Unlisted } \\
\text { Target }\end{array}$ & $\begin{array}{l}\text { Relative } \\
\text { Deal Size }\end{array}$ & $\begin{array}{l}\text { Block } \\
\text { Votes }\end{array}$ & $\begin{array}{c}\text { Ln Total } \\
\text { Assets }\end{array}$ & $\begin{array}{c}\text { Tobin's } \\
\text { Q }\end{array}$ & $\begin{array}{l}\text { Free } \\
\text { Cash } \\
\text { Flow }\end{array}$ & Leverage & $\begin{array}{l}\text { Std } \\
\text { Dev }\end{array}$ \\
\hline $\begin{array}{l}\text { Common } \\
\text { Law }\end{array}$ & 1.000 & & & & & & & & \\
\hline $\begin{array}{l}\text { Unlisted } \\
\text { Target }\end{array}$ & $\begin{array}{c}-0.153 \\
0.012\end{array}$ & 1.000 & & & & & & & \\
\hline $\begin{array}{l}\text { Relative } \\
\text { Deal Size }\end{array}$ & $\begin{array}{c}-0.115 \\
0.062\end{array}$ & $\begin{array}{c}-0.199 \\
0.001\end{array}$ & 1.000 & & & & & & \\
\hline $\begin{array}{l}\text { Blockholde } \\
\text { r Votes }\end{array}$ & $\begin{array}{c}-0.111 \\
0.071\end{array}$ & $\begin{array}{c}-0.028 \\
0.645\end{array}$ & $\begin{array}{l}0.162 \\
0.008\end{array}$ & 1.000 & & & & & \\
\hline $\begin{array}{l}\text { Ln Total } \\
\text { Assets }\end{array}$ & $\begin{array}{l}0.203 \\
0.000\end{array}$ & $\begin{array}{c}-0.166 \\
0.006\end{array}$ & $\begin{array}{c}-0.183 \\
0.002\end{array}$ & $\begin{array}{c}-0.324 \\
0.000\end{array}$ & 1.000 & & & & \\
\hline Tobin's Q & $\begin{array}{l}0.045 \\
0.463\end{array}$ & $\begin{array}{l}0.114 \\
0.062\end{array}$ & $\begin{array}{l}0.047 \\
0.446\end{array}$ & $\begin{array}{l}0.049 \\
0.424\end{array}$ & $\begin{array}{c}-0.348 \\
0.000\end{array}$ & 1.000 & & & \\
\hline $\begin{array}{l}\text { Free Cash } \\
\text { Flow }\end{array}$ & $\begin{array}{l}0.126 \\
0.040\end{array}$ & $\begin{array}{c}-0.009 \\
0.877\end{array}$ & $\begin{array}{c}-0.013 \\
0.829\end{array}$ & $\begin{array}{l}0.133 \\
0.030\end{array}$ & $\begin{array}{l}0.071 \\
0.245\end{array}$ & $\begin{array}{l}0.172 \\
0.004\end{array}$ & 1.000 & & \\
\hline Leverage & $\begin{array}{r}-0.017 \\
0.778\end{array}$ & $\begin{array}{l}0.118 \\
0.053\end{array}$ & $\begin{array}{c}-0.045 \\
0.460\end{array}$ & $\begin{array}{c}-0.154 \\
0.011\end{array}$ & $\begin{array}{l}0.220 \\
0.000\end{array}$ & $\begin{array}{l}-0.195 \\
0.001\end{array}$ & $\begin{array}{l}0.027 \\
0.654\end{array}$ & 1.000 & \\
\hline Std Dev & $\begin{array}{c}-0.073 \\
0.235\end{array}$ & $\begin{array}{l}0.038 \\
0.527\end{array}$ & $\begin{array}{l}0.176 \\
0.003\end{array}$ & $\begin{array}{c}-0.022 \\
0.712\end{array}$ & $\begin{array}{c}-0.366 \\
0.000\end{array}$ & $\begin{array}{l}0.325 \\
0.000\end{array}$ & $\begin{array}{c}-0.298 \\
0.000\end{array}$ & $\begin{array}{c}-0.205 \\
0.000\end{array}$ & 1.000 \\
\hline
\end{tabular}

Common Law is equal to one if target's country regulation is Common Law (La Porta et al., 1998), and zero otherwise. Unlisted Target is equal to one if the target is unlisted firm, and zero otherwise. Relative Deal Size is the deal value divided by acquirer's market value of assets. Blockholder Votes is voting rights of the ultimate shareholder. Ln Total Assets is the logarithm of book value of assets. Tobin's $Q$ is the sum of market value of assets and long term debt divided by the book value of assets. Free Cash Flow is cash divided by book value of assets. Leverage is long term debt divided by book value of assets. Standard Dev is the standard deviation of stock returns measured at the estimation period ($261 ;-11)$. 